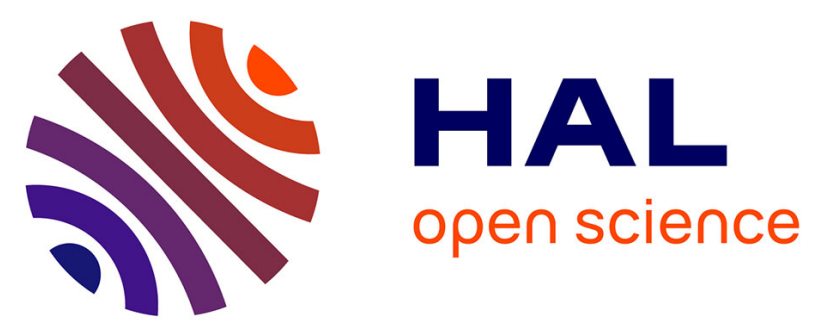

\title{
Trimetallic Cubane-Type Clusters Transition-Metal Variation as a Probe of the Roots of Hypoelectronic Metallaheteroboranes
}

Sourav Kar, Koushik Saha, Suvam Saha, Bakthavachalam Kirubakaran, Vincent Dorcet, Sundargopal Ghosh

\section{To cite this version:}

Sourav Kar, Koushik Saha, Suvam Saha, Bakthavachalam Kirubakaran, Vincent Dorcet, et al.. Trimetallic Cubane-Type Clusters Transition-Metal Variation as a Probe of the Roots of Hypoelectronic Metallaheteroboranes. Inorganic Chemistry, 2018, 57 (17), pp.10896-10905. 10.1021/acs.inorgchem.8b01531 . hal-01862463

HAL Id: hal-01862463

https://hal-univ-rennes1.archives-ouvertes.fr/hal-01862463

Submitted on 14 Sep 2018

HAL is a multi-disciplinary open access archive for the deposit and dissemination of scientific research documents, whether they are published or not. The documents may come from teaching and research institutions in France or abroad, or from public or private research centers.
L'archive ouverte pluridisciplinaire HAL, est destinée au dépôt et à la diffusion de documents scientifiques de niveau recherche, publiés ou non, émanant des établissements d'enseignement et de recherche français ou étrangers, des laboratoires publics ou privés. 


\section{Trimetallic Cubane-type Clusters: Transition metal Variation as a Probe of the Roots of Hypoelectronic}

\section{Metallaheteroboranes}

Sourav Kar, ${ }^{\dagger}$ Koushik Saha, ${ }^{\dagger}$ Suvam Saha, ${ }^{\dagger}$ Bakthavachalam Kirubakaran, ${ }^{\dagger}$ Vincent Dorcet $^{\ddagger}$ and Sundargopal Ghosh*, ${ }^{\dagger}$

${ }^{\dagger}$ Department of Chemistry, Indian Institute of Technology Madras, Chennai 600036, India. Tel:

+91 44-22574230; Fax: +91 44-22574202; E-mail: sghosh@iitm.ac.in

${ }^{\ddagger}$ Institut des Sciences Chimiques de Rennes, UMR 6226 CNRS-Ecole Nationale Supérieure de Chimie de Rennes-Université de Rennes 1, F-35042 Rennes Cedex, France. E-mail: vincent.dorcet@univ-rennes1.fr

Keywords: metallaheteroborane, adamantane, thioborate 


\section{ABSTRACT}

In an effort to synthesize the chalcogen-rich metallaheteroborane clusters of group 5 metals, thermolysis of $\left[\mathrm{Cp}^{*} \mathrm{TaCl}_{4}\right]\left(\mathrm{Cp} *=\eta^{5}-\mathrm{C}_{5} \mathrm{Me}_{5}\right)$ with thioborate ligand $\mathrm{Li}\left[\mathrm{BH}_{2} \mathrm{~S}_{3}\right]$ was carried out that afforded trimetallic clusters $\left[(\mathrm{Cp} * \mathrm{Ta})_{3}(\mu-\mathrm{S})_{3}\left(\mu_{3}-\mathrm{S}\right)_{3} \mathrm{~B}(\mathrm{R})\right], \mathbf{1 - 3}(\mathbf{1}: \mathrm{R}=\mathrm{H}, \mathbf{2}$ : $\mathrm{R}=\mathrm{SH}$, and 3: $\mathrm{R}=\mathrm{Cl}$ ). Clusters 1, 2 and $\mathbf{3}$ are illustrious examples of cubane-type organotantalum sulfido clusters in which one of the vertices of the cubane is missing. In parallel to the formation of 1-3, the reaction also yielded tetrametallic sulfido cluster $\left[\left(\mathrm{Cp}^{*} \mathrm{Ta}\right)_{4}(\mu-\mathrm{S})_{6}\left(\mu_{3}-\mathrm{S}\right)\left(\mu_{4}-\mathrm{O}\right)\right], \mathbf{6}$, having an adamantane core structure. Compound $\mathbf{6}$ is one of the rarest examples containing $\mu_{4}-$ oxo unit with heavier early transition metal i.e. tantalum. In an effort to isolate selenium analogues of clusters 1-3, we have isolated the trimetallic cluster $\left[(\mathrm{Cp} * \mathrm{Ta})_{3}(\mu-\mathrm{Se})_{3}\left(\mu_{3}-\mathrm{Se}\right)_{3} \mathrm{~B}(\mathrm{H})\right], \mathbf{4}$ from the thermolytic reaction of $\left[\mathrm{Cp}^{*} \mathrm{TaCl}_{4}\right]$ and $\mathrm{Li}\left[\mathrm{BH}_{2} \mathrm{Se}_{3}\right]$. In contrast, the thermolysis of $\left[\mathrm{Cp}^{*} \mathrm{TaCl}_{4}\right]$ with $\mathrm{Li}\left[\mathrm{BH}_{2} \mathrm{Te}_{3}\right]$ under the same reaction conditions yielded tantalum telluride complex $\left[(\mathrm{Cp} * \mathrm{Ta})_{2}(\mu-\mathrm{Te})_{2}\right], 5$. Compounds 1-4 are hypo-electronic clusters with an electron count of 50

cve (cve = cluster valence electrons). All these compounds have been characterized by the ${ }^{1} \mathrm{H}$, ${ }^{11} \mathrm{~B}\left\{{ }^{1} \mathrm{H}\right\},{ }^{13} \mathrm{C}\left\{{ }^{1} \mathrm{H}\right\}$ NMR spectroscopy, IR spectroscopy, mass spectrometry and single crystal Xray crystallography. The density functional theory (DFT) calculations were also carried out to provide insight into the bonding and electronic structures of these molecules.

\section{INTRODUCTION}

Transition-metal-boron chemistry, comprehending a wide range of structural diversities with higher nuclearity metallaborane clusters to complexes with single boron, has sustained to gain continuous interest. ${ }^{1,2}$ In this regard, single boron-metal-chalcogen clusters are advancing in the rapidly growing metallaheteroboranes family, mostly due to their intriguing structure and 
bonding. The chemistry of transition metal complexes with main group elements ${ }^{3}$ particularly with chalcogen ligands is of substantial importance due to their widespread use in the preparation of advanced materials ${ }^{4 \mathrm{a}-\mathrm{c}}$ and industrial catalysis. ${ }^{4 \mathrm{~d}, \mathrm{e}}$ These complexes also play a significant role in the activity of metalloproteins in enzymatic catalytic cycle. ${ }^{5}$ The homo and heterometallic sulfido complexes with wide range of substrates are well documented in the literature. ${ }^{6-13}$ For example, $\left[\left(\mathrm{C}_{5} \mathrm{H}_{4} \mathrm{CH}_{3}\right)_{2} \mathrm{~V}_{2} \mathrm{~S}_{5}\right],{ }^{14 \mathrm{a}}\left[(\mathrm{CpCr})_{2} \mathrm{~S}(\mathrm{~S}-t-\mathrm{Bu})_{2}\right],{ }^{14 \mathrm{~b}}\left[\mathrm{Fe}_{2} \mathrm{~S}_{2}(\mathrm{CO})_{6}\right],{ }^{15 \mathrm{a}}\left[\mathrm{Mn}_{2}(\mathrm{CO})_{7}\left(\mu-\mathrm{S}_{2}\right)\right],{ }^{15 \mathrm{~b}}$ $\left[\mathrm{Cp}_{2} \mathrm{TiE}_{5}\right](\mathrm{E}=\mathrm{S}$ or Se$),{ }^{16}$ and $\left[\mathrm{Cp}_{2}{ }_{2} \mathrm{Mo}_{2} \mathrm{~S}_{4}\right]^{17}$ have been involved in many organic synthesis, assembly of uncommon mixed-metal clusters and used as hydrogenation catalysts.

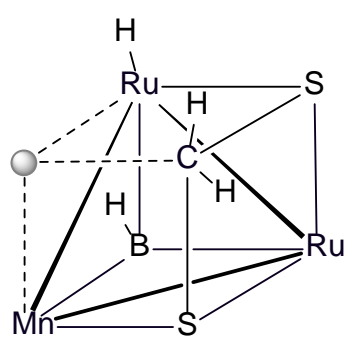

I; $\left[\mathrm{Mn}=\mathrm{Mn}(\mathrm{CO})_{3}\right.$,

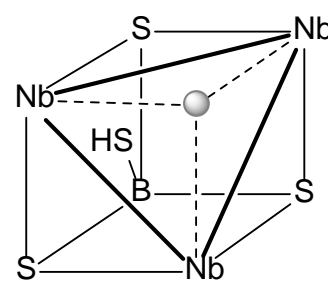

II; $\left[\mathrm{Nb}=\mathrm{Cp}^{+} \mathrm{Nb}\right]$ $-0_{\substack{\prime \\ 1}}^{\prime}=$ missing vetrex

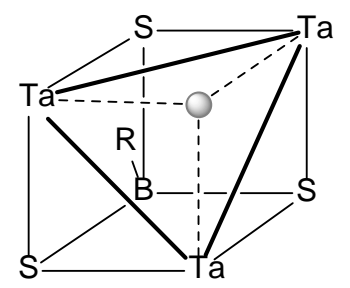

1, 2 or 3; $[\mathrm{R}=\mathrm{H}$ or $\mathrm{SH}$ or $\mathrm{Cl}$, $\left.\mathrm{Ta}=\mathrm{Cp}{ }^{*} \mathrm{Ta}\right]$

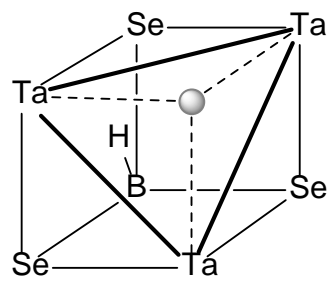

$4 ;\left[\mathrm{Ta}=\mathrm{Cp} \mathrm{p}^{\star T a}\right]$

Chart 1. Metal and chalcogen-rich metallaheteroborane cubane-type clusters with one missing vertex (only the core geometry of II and 1-4 are shown for clarity).

In contrast, thioborates are not regularly seen in the coordination sphere of transition metals, mostly due to the lack of synthetic routes. However, after the discovery of tetrathioborate containing complex, $\left[\left\{\mathrm{Cp}^{+} \mathrm{Nb}\right\}_{3}(\mu-\mathrm{S})_{3}\left(\mu_{3}-\mathrm{S}\right)_{3} \mathrm{~B}(\mathrm{SH})\right]$ by Wachter, an investigation of related vanadium and tantalum systems became of interest. ${ }^{18}$ Although, the geometry of this tetrathioborate niobium complex was not fully defined, it may be considered as a cubane-type cluster having a $\mathrm{M}_{3} \mathrm{E}_{4}$ core. Cubane is a very well-known framework in the field of organometallic chemistry that has been used as model in various biological and industrial 
process. ${ }^{19-20}$ There are not many incomplete cubane-type clusters known, however, recently, our group reported a cubane-type cluster $\left[(\mathrm{Cp} * \mathrm{Ru})_{2} \mathrm{Mn}(\mathrm{CO})_{3} \mathrm{BH}_{2}\left(\mathrm{CS}_{2} \mathrm{H}_{2}\right)\right]$ which contains $\mathrm{M}_{3} \mathrm{E}_{4}$ core. ${ }^{21}$ Although in 1997, Tatsumi isolated and structurally characterized the trithioborate complex $\left[(\mathrm{Cp} * \mathrm{Ta})_{3}(\mu-\mathrm{S})_{3}\left(\mu_{3}-\mathrm{S}\right)_{3} \mathrm{~B}(\mathrm{H})\right], 1$ using two steps synthetic route, the chemistry was not explored with heavier chalcogen elements. ${ }^{22}$ Upon careful analysis of the single crystal X-ray structure of $\mathbf{1}$, we assumed that the $\mathrm{Ta}_{3}$ framework in $\mathbf{1}$ is stabilized by trithioborate $\left(\mathrm{BHS}_{3}{ }^{-}\right)$ ligand. As a result, we introduced a simple and accessible synthetic route i.e. reaction of $\left[\mathrm{Cp} * \mathrm{TaCl}_{4}\right]$ with trichalcogenoborate $\mathrm{Li}\left[\mathrm{BH}_{2} \mathrm{E}_{3}\right],{ }^{23-25}(\mathrm{E}=\mathrm{S}$ or Se or Te). Herein, we report the isolation and structural elucidation of various chalcogen-stabilized metallaheteroboranes that show rare cubane-type clusters. In addition, theoretical calculations have established the stability and bonding of the new metallaheteroborane clusters.

\section{RESULTS AND DISCUSSION}

Reaction of $\left[\mathbf{C p}^{*} \mathrm{TaCl}_{4}\right]$ with $\mathrm{Li}\left[\mathrm{BH}_{2} \mathbf{E}_{3}\right](\mathbf{E}=\mathbf{S}$ or Se or Te). As shown in the Scheme 1, thermolysis of $\left[\mathrm{Cp}^{*} \mathrm{TaCl}_{4}\right]$ with four equivalents of $\mathrm{Li}\left[\mathrm{BH}_{2} \mathrm{E}_{3}\right](\mathrm{E}=\mathrm{S}$ or Se) (prepared from the low temperature reaction of $\left[\mathrm{LiBH}_{4} \cdot \mathrm{THF}\right]$ and chalcogen powders) resulted in the formation of $\left[(\mathrm{Cp} * \mathrm{Ta})_{3}(\mu-\mathrm{E})_{3}\left(\mu_{3}-\mathrm{E}\right)_{3} \mathrm{~B}(\mathrm{R})\right],(\mathbf{1}: \mathrm{E}=\mathrm{S}, \mathrm{R}=\mathrm{H} ; \mathbf{2}: \mathrm{E}=\mathrm{S}, \mathrm{R}=\mathrm{SH} ; \mathbf{3}: \mathrm{E}=\mathrm{S}, \mathrm{R}=\mathrm{Cl}$ and 4: $\mathrm{E}=\mathrm{Se}$, $\mathrm{R}=\mathrm{H})$. The ${ }^{11} \mathrm{~B}\left\{{ }^{1} \mathrm{H}\right\}$ NMR spectra of $\mathbf{1 - 4}$ show single resonance appeared each at $\delta=0.3,1.2$, 5.6 and -11.2 ppm respectively. The ${ }^{13} \mathrm{C}\left\{{ }^{1} \mathrm{H}\right\}$ and ${ }^{1} \mathrm{H}$ NMR spectra suggest the presence of symmetry in 1-4 with respect to the Cp* ligands. In addition, ${ }^{1} \mathrm{H}$ NMR chemical shifts at $\delta=4.74$ and $4.71 \mathrm{ppm}$ confirmed the presence of a terminal B-H proton for compounds $\mathbf{1}$ and $\mathbf{4}$ respectively. Furthermore, the presence of terminal B-H proton for $\mathbf{4}$ and S-H proton for $\mathbf{2}$ were confirmed by IR spectroscopy. The single crystal X-ray diffraction analyses were carried out to 
endorse the spectroscopic assignments and to conclude the solid-state $\mathrm{X}$-ray structures of compounds 1-4.
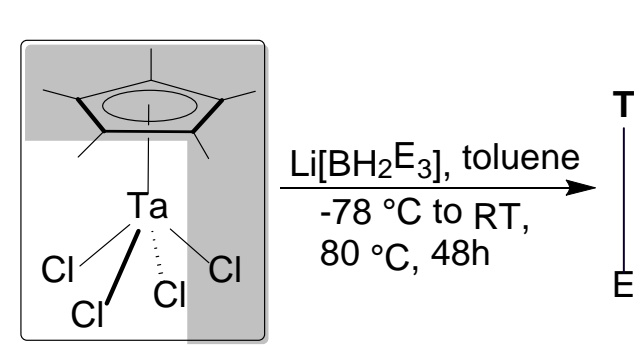

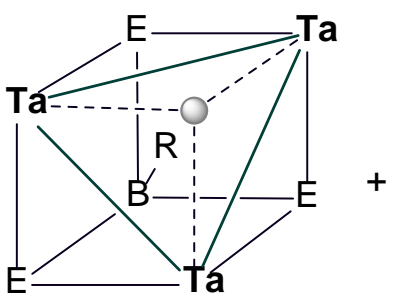

1: $E=S, R=H$

2: $\mathrm{E}=\mathrm{S}, \mathrm{R}=\mathrm{SH}$

3: $E=S, R=C l$

4: $E=S e, R=H$

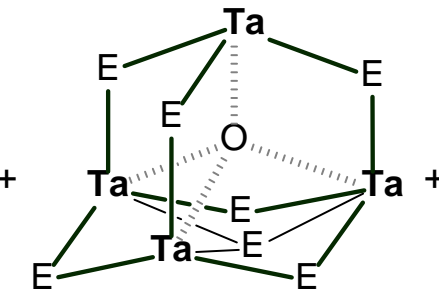

6: $E=S$

$--_{\substack{\prime \\ 1}}^{\prime}=$ missing vertex
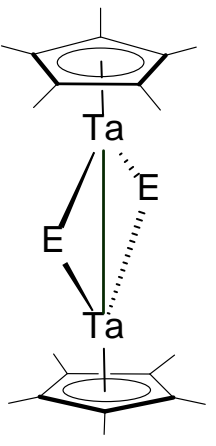

5: $\mathrm{E}=\mathrm{Te}$

Scheme 1. Synthesis of chalcogen-rich tantallaboranes (1-4) and inorganic adamantane type cluster (6) ( $\mu$-S in clusters 1, 2 and 3, and $\mu$-Se in $\mathbf{4}$ are not shown for clarity; Ta $=\mathrm{Cp} * \mathrm{Ta}$ ).

The solid-state X-ray structure analysis of 1-4 shows that these molecules consist of an equilateral $\mathrm{Ta}_{3}$ triangular core and the edges of the $\mathrm{Ta}_{3}$-triangle are bridged by six monosulfide (for 1, 2 and 3) and monoselenide (for 4) atoms. In case of 1, 2 and 3, three sulfide units are capped by $\{\mathrm{B}(\mathrm{H})\},\{\mathrm{B}(\mathrm{SH})\}$ and $\{\mathrm{B}(\mathrm{Cl})\}$ fragments respectively. Three selenide units are bridged by $\{\mathrm{B}(\mathrm{H})\}$ fragment in 4 . The mean B-S and B-Se bond distances are comparable with the distance observed in $\mathrm{BE}_{3} \mathrm{R}(\mathrm{E}=\mathrm{S}$ or $\mathrm{Se}$ ) tetrahedron. The existence of compounds 1-3 and 4 permits a structural and spectroscopic comparison with other cubane-type clusters containing different chalcogenoborate ligands (Table 1). It is interesting to note that the clusters in which the boron atom is coordinated to heavier chalcogen atoms i.e. selenium, the ${ }^{11} \mathrm{~B}$ chemical shift appeared at upfield region compared to its sulfur analogue. Note that, Tatsumi reported compound $\mathbf{1}$ with low yield and the authors faced some difficulties in detecting the proton bound to boron in ${ }^{1} \mathrm{H}$ NMR spectrum. Having isolated $\mathbf{1}$ in good yield, we were able to reinvestigate the 
spectroscopic characterizations. The ${ }^{1} \mathrm{H}$ chemical shift for the proton bound to boron appeared at $\delta=4.74 \mathrm{ppm}$. Further, the ${ }^{11} \mathrm{~B}\left\{{ }^{1} \mathrm{H}\right\}$ NMR spectrum revealed a peak at $\delta=0.3 \mathrm{ppm}$, which is very downfield shifted as compared to the ${ }^{11} \mathrm{~B}$ chemical shift reported by Tatsumi $(\delta=-21.3 \mathrm{ppm})$.

As shown in Figure 1, the geometries of 1-4 can be considered as cubane-type clusters with a missing vertex. According to wade's rules, the stable electron count for a $M_{4} E_{4}$ type cubane is $(15 \times 4+5 \times 4)=80$, in which there is no M-M or M-E bond present along the diagonals of the cube. The presence of M-M or M-E bonds alter the cluster electron counts, for example, each successive loss or gain of 2 electrons are supplemented by the formation or breaking of M-M/M- E bond respectively. ${ }^{1 \mathrm{a}}$ Earlier, Kennedy and his coworkers ${ }^{26}$ proposed the cluster electron counts for the cubanes $\left[(\mathrm{CpNi})_{4} \mathrm{~B}_{4} \mathrm{H}_{4}\right]^{27}$ and $\left[(\mathrm{Cp} * \mathrm{Ru})_{3}\left(\mu_{3}-\mathrm{CO}\right) \mathrm{Co}(\mathrm{CO})_{2} \mathrm{~B}_{3} \mathrm{H}_{3}\right]^{28}$ as 68 and 60 with two and six metal-metal bonds respectively. Cubane cluster $\left[(\mathrm{Cp} * \mathrm{Ru})_{3}\left(\mu_{3^{-}}\right.\right.$ $\mathrm{CO}) \mathrm{Co}(\mathrm{CO})_{2} \mathrm{~B}_{3} \mathrm{H}_{3}$ ] can also be described as tetracapped tetrahedron. Earlier, from our group we have reported a $\mathrm{M}_{3} \mathrm{E}_{4}$ type of

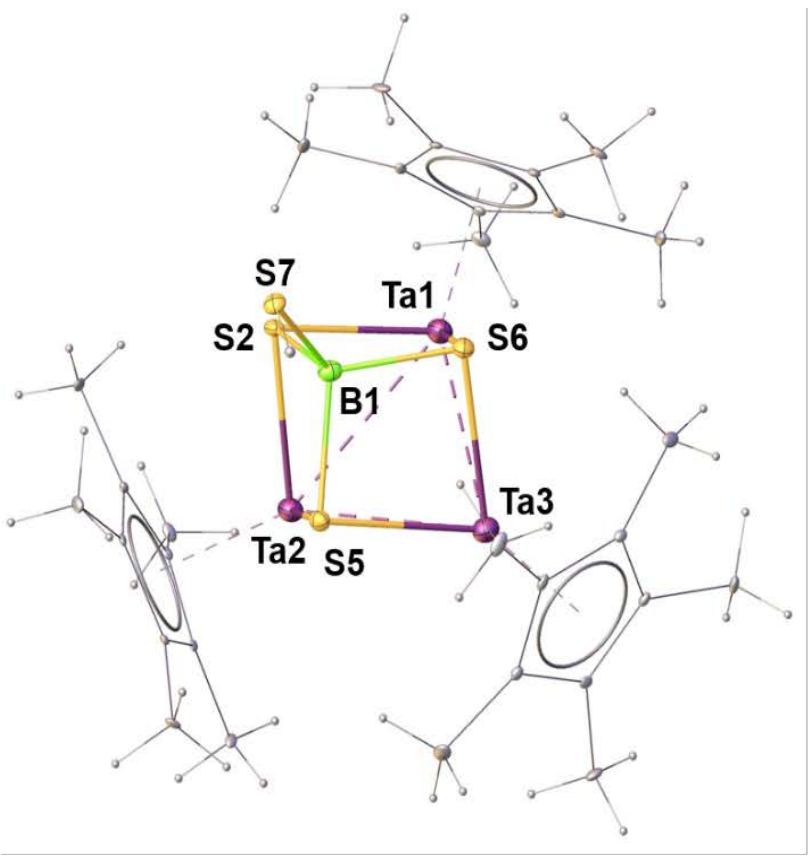

(a)

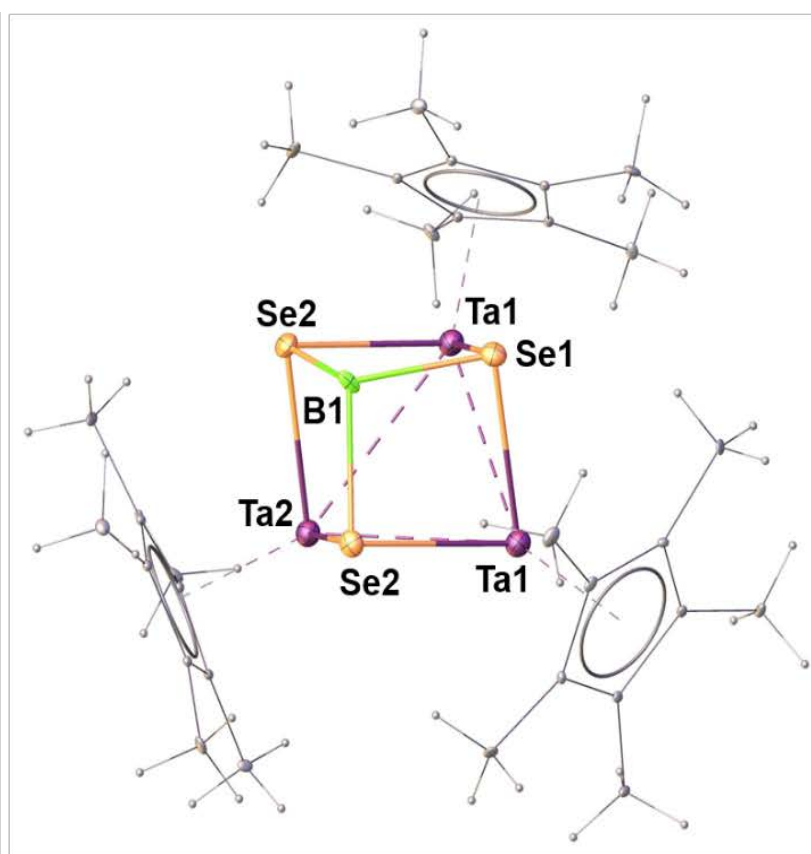

(b) 
Figure 1. Molecular structures and labeling diagrams of 2 (a) and 4 (b). Selected bond lengths (A) and angles $\left(^{\circ}\right)$ : 2: Ta1-Ta3 3.0974(6), Ta1-Ta2 3.1153(6), Ta2-Ta3 3.1054(7), B1-S6 1.899(16), B1-S7 1.854(15), Ta1-Ta3-Ta2 60.296(15), Ta3-Ta2-Ta1 59.725(15), S6-B1-S2 104.3(7), Ta2-S5-Ta3 75.57(8); 4: Ta1-Ta2 3.213(2), Тa1-Ta2 3.2376(19), Ta1-Тa1 3.213(2), B1-Se1 2.02(5), B1-Se2 2.12(4), Ta1-Ta1-Ta2 60.25(2), Ta2-Se2-Ta1 74.76(8).

Table 1. Selected structural parameters and spectroscopic data of chalcogen-rich cubane-type clusters of group 5 metals.

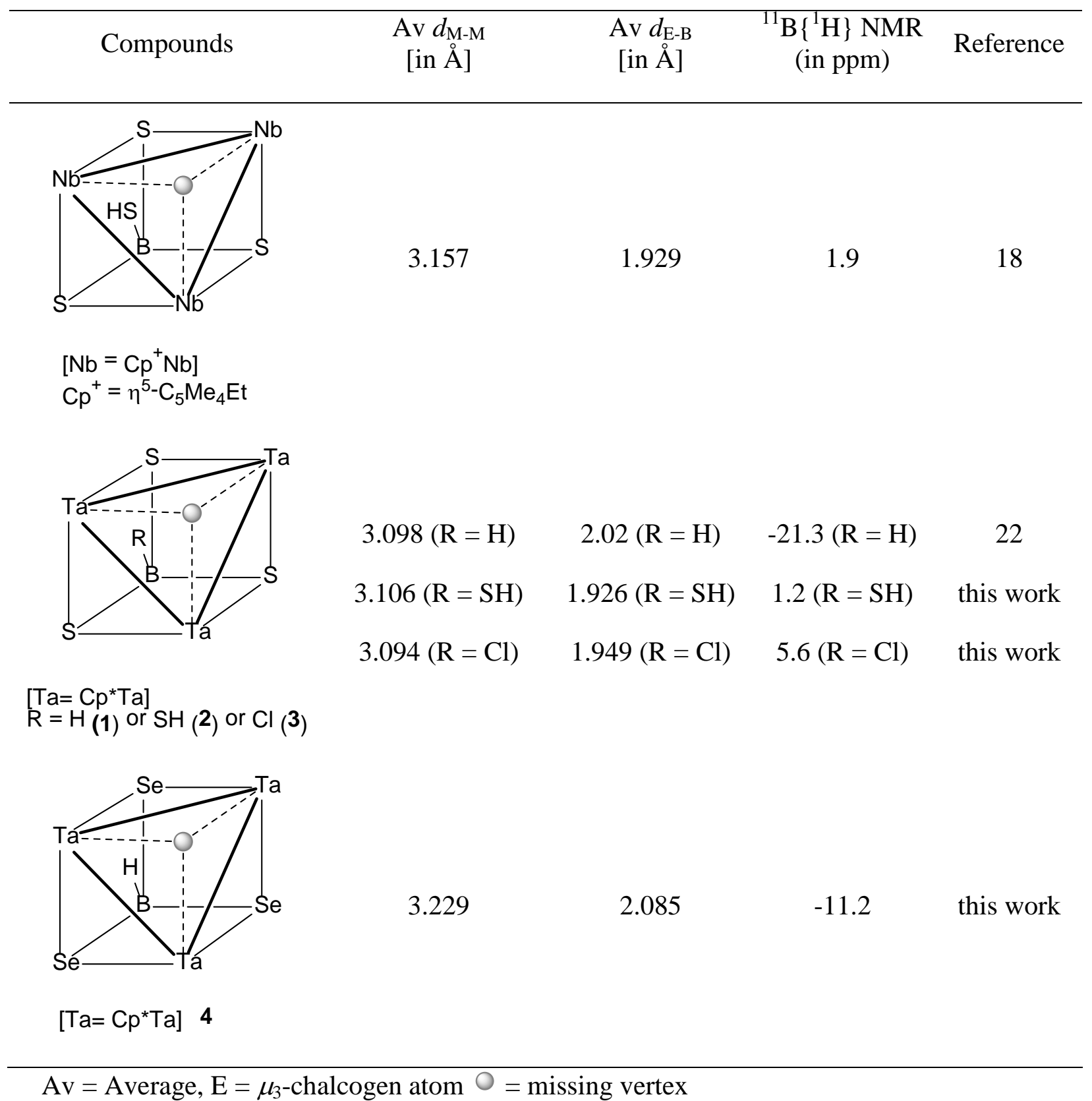


cubane cluster, $\left[(\mathrm{Cp} * \mathrm{Ru})_{2} \mathrm{Mn}(\mathrm{CO})_{3} \mathrm{BH}_{2}\left(\mathrm{CS}_{2} \mathrm{H}_{2}\right)\right]$ that can be derived from $\mathrm{M}_{4} \mathrm{E}_{4}$ by removing one metal vertex. As one transition metal vertex is missing and three $\mathrm{M}-\mathrm{M}$ bonds are present, total valence electron count for this molecule should be $\{80-18-(3 \times 2)\}=56$, however the actual electron count is 54 . Similarly, for molecule $\left[\left(\mathrm{Cp}^{+} \mathrm{Nb}\right)_{3} \mathrm{BHS}_{7}\right]$, reported by Wachter, consists of 50 cve. The metal sulfido and selenido clusters, $\mathrm{Ta}_{3} \mathrm{~S}_{3} \mathrm{~B}$ or $\mathrm{Ta}_{3} \mathrm{Se}_{3} \mathrm{~B}$ (1-4), can very well be related with $\left[\left(\mathrm{Cp}^{+} \mathrm{Nb}\right)_{2} \mathrm{BHS}_{7}\right]$. Clusters 1-4 also consist $50 \mathrm{cve}$, which is 6 electrons short of the regular one (if we apply Kennedy’s Scheme). Thus, these cubane-type clusters, having a missing vertex, can be defined as hypo-electronic clusters.

To get insight into the structure and bonding of 1-4, computational analyses on the ground of DFT (Density Functional Theory) ${ }^{29}$ at PBE0/Def2-SVP level were carried out. The frontier molecular orbitals of 1-4 showed that the HOMO of 1-4 made of $\mathrm{d}_{\mathrm{z}}{ }^{2}$ orbitals of three Ta atoms and they are delocalized over three Ta atoms to form a $\mathrm{Ta}_{3}$ triangular framework (Figures S26). The analyses further showed that the HOMO of $\mathbf{3}$ is further stabilized in contrast to others, which may be due to the presence of electronegative $\mathrm{Cl}$ atom attached to the boron. The energy gap between HOMO and LUMO of 1-4 indicate the stability of such hypo-electronic cubanetype clusters.

In an attempt to isolate the Te analogue of $\mathbf{1 - 4}$, we explored the reactivity of $\mathrm{Li}\left[\mathrm{BH}_{2} \mathrm{Te}_{3}\right]$ with $\left[\mathrm{Cp} * \mathrm{TaCl}_{4}\right]$ in toluene at $80{ }^{\circ} \mathrm{C}$ that resulted in the formation of compound $\mathbf{5}$. Although the reaction yielded some very low yielded compounds, they were too less in amount and highly unstable to be isolated. Compound 5 was isolated as yellow solid. The ${ }^{1} \mathrm{H}$ and ${ }^{13} \mathrm{C}\left\{{ }^{1} \mathrm{H}\right\}$ NMR spectroscopic data displayed the presence of one $\mathrm{Cp}$ * environment and the ${ }^{11} \mathrm{~B}\left\{{ }^{1} \mathrm{H}\right\}$ NMR showed no peak that excludes the formation of any metallaborane cluster. Finally, the solid state X-ray diffraction analysis on a suitable crystal of $\mathbf{5}$ was performed to elucidate the structure of $\mathbf{5}$. 
As shown in Figure S4, the molecular structure of $\mathbf{5}$ can be described as two $\{\mathrm{Cp} * \mathrm{Ta}\}$ units held together by two $\mu_{2}$-bridging telluride ligands. Both the two Ta and Te atoms are not in same plane. Although, there are known examples of Te bridged Ta complex (such as IV, Chart 2), they were mostly characterized by NMR, IR spectroscopy and to the best of our knowledge no solidstate X-ray structures are known till date. ${ }^{30,31}$

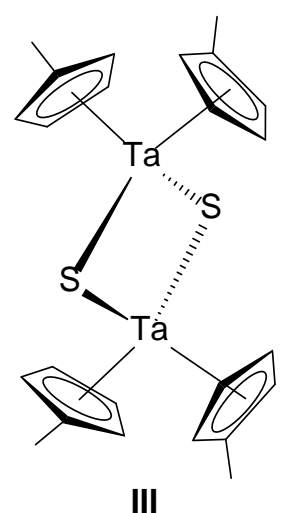

III

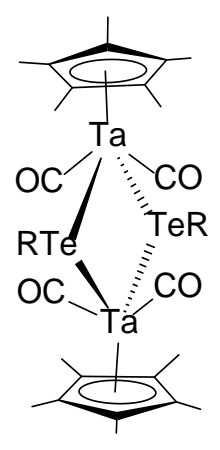

IV $, \mathrm{R}=\mathrm{Ph}, \mathrm{Me}$

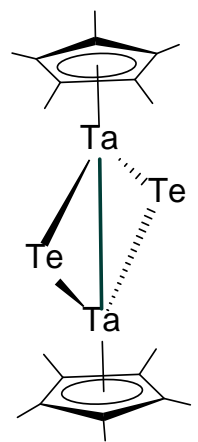

5

Chart 2. Binuclear Ta complexes containing bridging chalcogen atoms.

Having failed to isolate the Te analogue of $\mathbf{1}$, we were curious to examine their apparent stabilities ( $\mathbf{1}^{\mathrm{Te}}$, Te analogue of $\left.\mathbf{1}\right)$. The calculated HOMO-LUMO gap for $\mathbf{1}^{\mathrm{Te}}$ revealed that as one changes the chalcogen atom from $\mathrm{S}$ to Te, the apparent thermodynamic stability increases in the order $\mathbf{1}^{\mathrm{Te}}<\mathbf{4}<\mathbf{1}$. These results have also been verified with the calculated natural charges on boron $\left(q_{\mathrm{B}}\right)$ and chalcogen atoms $\left(q_{\mathrm{E}}\right)$ (Table S1). The positive charge on boron converted to negative and goes more negative when chalcogen atoms are changed from $\mathrm{S}$ to Te. Whereas, the charge on chalcogen increases in the order $\mathrm{S}<\mathrm{Se}<\mathrm{Te}$. The chalcogen atom donates its electron density to the boron, which is the sign of an increase in natural valence population at boron center and a decrease at chalcogen atom. This study indirectly suggests that the synthesis of the Te analogue is synthetically challenging. 


\section{Tetrametallic $\mu_{4}$-oxo cluster, 6:}

As shown in the Scheme 1, along with the formation of 1-3, thermolysis of $\left[\mathrm{Cp}^{*} \mathrm{TaCl}_{4}\right]$ with four equivalents of $\mathrm{Li}\left[\mathrm{BH}_{2} \mathrm{~S}_{3}\right]$ also yielded compound $\mathbf{6}$ as brown solid. It was characterized by ${ }^{1} \mathrm{H}$ and ${ }^{13} \mathrm{C}\left\{{ }^{1} \mathrm{H}\right\}$ NMR spectroscopy, mass spectrum and a single crystal X-ray crystallographic analysis. The ${ }^{11} \mathrm{~B}\left\{{ }^{1} \mathrm{H}\right\}$ NMR shows no peak and the ${ }^{1} \mathrm{H}$ NMR spectrum shows the presence of two Cp* ligands, appeared at $\delta=2.16$ and 2.01 ppm in 3:1 ratio. This indicates two different metal environments, which was further confirmed by ${ }^{13} \mathrm{C}\left\{{ }^{1} \mathrm{H}\right\}$ NMR spectrum. The mass spectrum of $\mathbf{6}$ displayed a molecular ion peak at m/z 1505.

An unambiguous explanation eluded us until an X-ray structure revealed the molecular formula of 6 as $\left[\left(\mathrm{Cp}^{*} \mathrm{Ta}\right)_{4}(\mu-\mathrm{S})_{6}\left(\mu_{3}-\mathrm{S}\right)\left(\mu_{4}-\mathrm{O}\right)\right]$. As shown in Figure 2, the solid-state X-ray structure of $\mathbf{6}$ represents adamantane like core. One of the most interesting features of $\mathbf{6}$ is the presence of six membered $\mathrm{Ta}_{3}-\mathrm{S}_{3}$ planar ring instead of a chair form. This may be due to the presence of $\mu_{3}-\mathrm{S}$ that brings three Ta atoms in one plane. Another noticeable feature of $\mathbf{6}$ is the presence of one $\mu_{4}$-oxo moiety inside the adamantane core. ${ }^{32}$ It is an example of inverse coordination complex, where non-metal oxygen is surrounded by four tantalum metals in a tetrahedral fashion. ${ }^{33-41}$ Inverse coordination compounds have noteworthy applications, such as, hydrogen gas storage, precursors for novel materials for catalysis and radioactive protective agents. ${ }^{34}$ The Ta-O bond length is slightly longer as compared to the M-O bond lengths observed in other adamantane-like inorganic compounds. ${ }^{38,41,42}$

As shown in Table 2, a series of adamantane-like inorganic compounds of various transition metals, (such as, $\mathrm{Cu},{ }^{34-37} \mathrm{Mg},{ }^{38} \mathrm{~Pb}^{39} \mathrm{Cr}^{40}$ and $\mathrm{Mn}^{41}$ ) are known and several of them are utilized in industrial catalysis to biomedical activity. Apart from the wide range of applications, 
their fascinating structural and bonding features make these complexes very important. Therefore, compound $\mathbf{6}$ could be a potential entry into the field of catalysis due to its structural similarity with other adamantane-like inorganic compounds. To the best of our knowledge, it is the first example

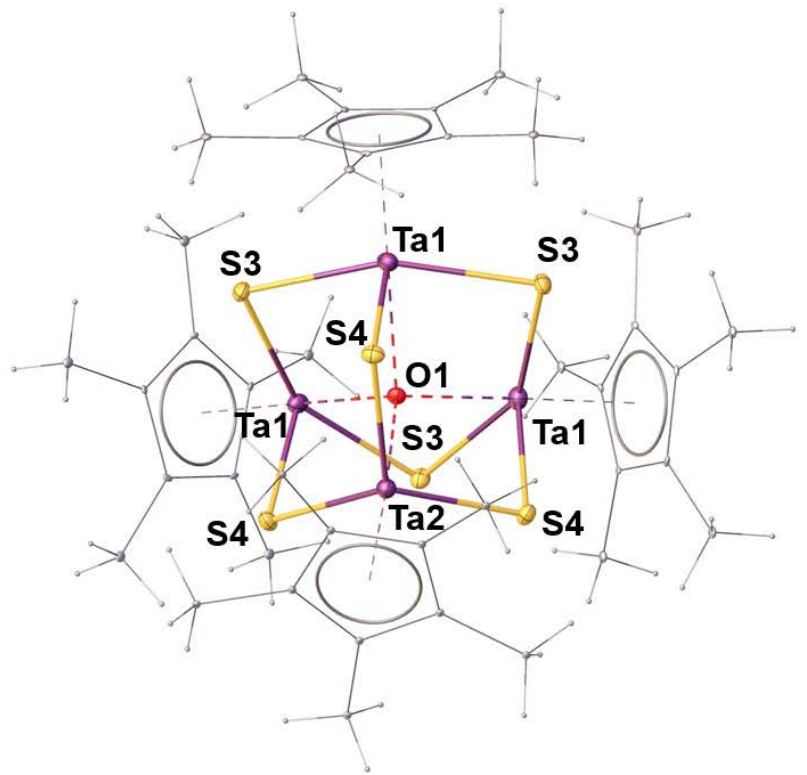

(a)

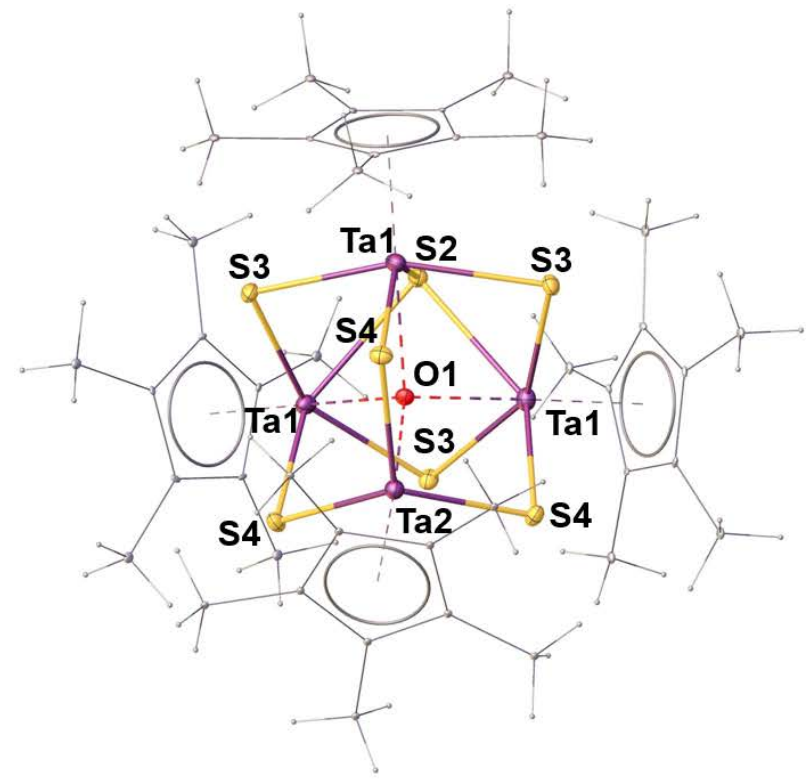

(b)

Figure 2. Molecular structure and labeling diagram of $\mathbf{6}$ without S2 (left side) and with S2 atom (right side). Selected bond lengths ( $\AA$ ) and angles $\left(^{\circ}\right)$ : Ta1-O1 2.174(4), Ta2-O1 2.064(10), Ta2S4 2.384(2), Ta1-S4 2.448(2); Ta1-O1-Ta2 115.0(2), Ta1-O1-Ta1 103.4(3), Ta1-S3-Ta1 89.68(8), Ta1-S4-Ta2 95.42(8).

of an oxo-centered adamantane-like inorganic compound comprising Ta and S. Although we have successfully isolated sulfur analogue of inorganic adamantane, all of our attempts to isolate the Se and Te analogue of $\mathbf{6}$ were failed. One of the reasons may be the higher atomic radius of Se and Te. The DFT investigation concur with our experimental observation. The frontier molecular orbital analysis clearly shows that the HOMO-LUMO gap reduces along the group 16 elements i.e. from S to Te, which gives an understanding for apparent instability of Se and Te 
analogues (Table S2). Further, the calculated natural charge and natural valence population show that moving from $\mathrm{S}$ to $\mathrm{Te}$, the electron density on oxygen as well as at chalcogen atoms was decreased and on tantalum the electron density was increased (Tables S2 and S3). In order to explain colors and corresponding HOMO- LUMO gaps of these complexes, the UV-Vis spectra were recorded in

Table 2. Structural parameters of selected $\mu_{4}$-oxo containing adamantane-like inorganic complexes.

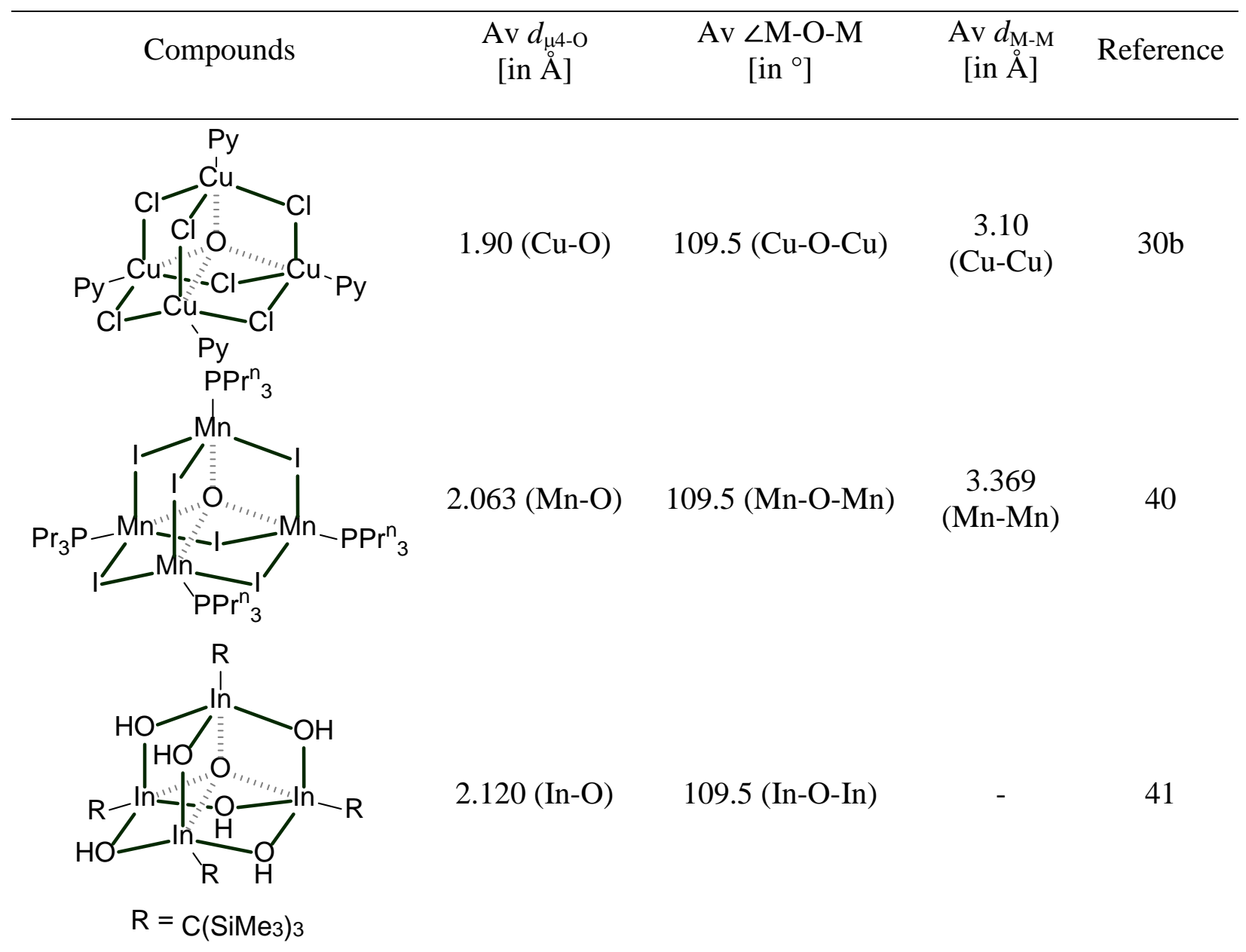




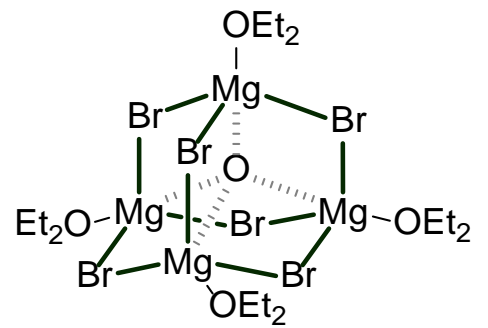

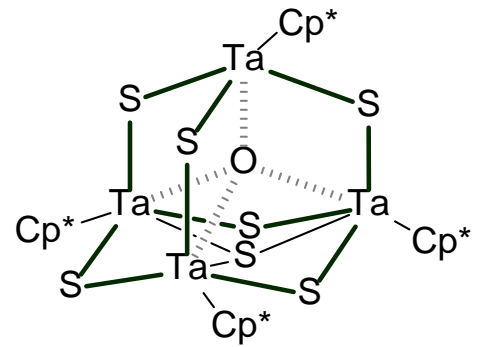

6

\subsection{6 (Тa-O) 109.2 (Тa-O-Тa) $3.493 \quad$ This}

Av = average, - = structural data not available

$\mathrm{CH}_{2} \mathrm{Cl}_{2}$. As shown in Figures S6-S8, compounds 1, 2 and $\mathbf{4}$ show absorption bands at $\lambda=428$, 423 and $500 \mathrm{~nm}$ respectively, which are consistent with their corresponding $\Delta \mathrm{E}$ values.

\section{CONCLUSION}

In summary, we have established a facile synthetic route for the synthesis of chalcogen-rich trimetallic cubane-type clusters 1-4. Our method overcomes the challenges, which was faced previously in isolating heavier chalcogen containing cubane-type cluster with tantalum. The theoretical study revealed the intriguing role of $\mathrm{Ta}_{3}$ triangular framework for the stabilization of the chalcogenoborate ligand. Furthermore, we have isolated and structurally characterized the first adamantane-like inorganic cluster comprising of tantalum and sulfur. This compound shows inverse coordination due to the presence of $\mu_{4}$-oxo unit. Thus, the discovery of this cluster may open the gateway for the synthesis of other group 5 transition metals containing adamantane-like clusters. 


\section{EXPERIMENTAL SECTION}

General Procedures and Instrumentation. All manipulations were conducted under an $\mathrm{Ar} / \mathrm{N}_{2}$ atmosphere by using standard Schlenk techniques or in a glove box. Solvents were distilled prior to use under an Ar atmosphere. $\left[\mathrm{Cp}^{*} \mathrm{TaCl}_{4}\right]^{42},\left[\mathrm{LiBH}_{4} \cdot \mathrm{THF}\right], \mathrm{S}$ powder, Se powder and Te powder were used as received (Aldrich). $\left.\mathrm{Li}\left[\mathrm{BH}_{2} \mathrm{E}_{3}\right)\right]^{23-25}(\mathrm{E}=\mathrm{S}$, Se and Te) were synthesized according to the literature methods. Thin layer chromatography was carried out on $250-\mu \mathrm{m}$ diameter aluminum supported silica gel TLC plates (MERCK TLC Plates) to separate the reaction mixtures. NMR spectra were recorded on $500 \mathrm{MHz}$ Bruker FT-NMR spectrometer. Residual solvent protons were used as reference $\left(\mathrm{CDCl}_{3}, \delta=7.26 \mathrm{ppm}\right)$, while a sealed tube that contained, $\left[\mathrm{Bu}_{4} \mathrm{~N}\left(\mathrm{~B}_{3} \mathrm{H}_{8}\right)\right]$ in $\left[\mathrm{D}_{6}\right]$ benzene $\left(\delta_{\mathrm{B}}=-30.07 \mathrm{ppm}\right)$ was used as an external reference for the ${ }^{11} \mathrm{~B}$ NMR analysis. ESI mass spectra were recorded on Bruker MicroTOF-II mass spectrometer. Infrared spectra were recorded with a JASCO FT/IR-4100 spectrometer. Absorption spectra were recorded with Evolution 300 (Thermo Scientific) UV/Vis spectrophotometer at $298 \mathrm{~K}$. Due to low yields and higher sensitivity of compounds 2, 3, 5 and $\mathbf{6}$, the elemental analysis of them were not carried out. On the other hand, our several attempts to obtain the elemental analysis data of the compounds $\mathbf{1}$ and $\mathbf{4}$ gave unsatisfactory results. Thus, the combustion analysis of all the compounds, reported in this paper, are not provided.

Synthesis of 1-3 and 6: In a flame-dried Schlenk tube [Cp*TaCl 4$](0.200 \mathrm{~g}, 0.44 \mathrm{mmol})$ was suspended in $20 \mathrm{~mL}$ toluene and chilled to $-78{ }^{\circ} \mathrm{C}$. It was added to a freshly prepared solution of $\mathrm{Li}\left[\mathrm{BH}_{2} \mathrm{~S}_{3}\right]$ in toluene. The reaction mixture was slowly warmed to room temperature over $1 \mathrm{~h}$ under stirring condition and then heated to $80{ }^{\circ} \mathrm{C}$ for $48 \mathrm{hrs}$. The volatile components were removed under vacuum and the residue was extracted into $n$-hexane and passed through Celite. After removal of the solvent, the residue was subjected to chromatographic work-up by using 
TLC plates. Elution with $n$-hexane/ $\mathrm{CH}_{2} \mathrm{Cl}_{2}\left(70: 30 \mathrm{v} / \mathrm{v}\right.$ ) yielded green 1 (solid, 0.092g, 18\%), ${ }^{43}$ green 2 (solid, 0.084g, 16\%), yellow 3 (solid, 0.026 g, 5\%) and brown 6 (solid, 0.053g, 8\%).

2: HRMS (ESI ${ }^{+}$): $\mathrm{m} / z$ calculated for $\mathrm{C}_{30} \mathrm{H}_{46} \mathrm{BS}_{7} \mathrm{Ta}_{3}+\mathrm{H}^{+}$: 1185.0256, found: 1185.0236. ${ }^{1} \mathrm{H}$ NMR (500 MHz, $\left.\mathrm{CDCl}_{3}, 22{ }^{\circ} \mathrm{C}\right): \delta=2.21 \mathrm{ppm}(\mathrm{s}, 45 \mathrm{H} ; 3 \times \mathrm{Cp} *) ;{ }^{11} \mathrm{~B}\left\{{ }^{1} \mathrm{H}\right\} \mathrm{NMR}\left(160 \mathrm{MHz}, \mathrm{CDCl}_{3}, 22\right.$ $\left.{ }^{\circ} \mathrm{C}\right): \delta=1.2 \mathrm{ppm} ;{ }^{13} \mathrm{C}\left\{{ }^{1} \mathrm{H}\right\}$ NMR $\left(125 \mathrm{MHz}, \mathrm{CDCl}_{3}, 22{ }^{\circ} \mathrm{C}\right): \delta=117.5\left(C_{5} \mathrm{Me}_{5}\right), 13.0 \mathrm{ppm}$ $\left(\mathrm{C}_{5} \mathrm{Me}_{5}\right)$; IR (hexane, $\left.\mathrm{cm}^{-1}\right)$ : $2431.8(\mathrm{~S}-\mathrm{H})$.

3: MS $\left(\mathrm{ESI}^{+}\right): \mathrm{m} / \mathrm{z}$ calculated for $\mathrm{C}_{30} \mathrm{H}_{45} \mathrm{BClS}_{6} \mathrm{Ta}_{3}+\mathrm{H}^{+}: 1187.0145$ found: $1187.0402 .{ }^{1} \mathrm{H}$ NMR (500 MHz, $\left.\mathrm{CDCl}_{3}, 22{ }^{\circ} \mathrm{C}\right): \delta=2.13 \mathrm{ppm}\left(\mathrm{s}, 45 \mathrm{H} ; 3 \times \mathrm{Cp}^{*}\right) ;{ }^{11} \mathrm{~B}\left\{{ }^{1} \mathrm{H}\right\}$ NMR $\left(160 \mathrm{MHz}, \mathrm{CDCl}_{3}, 22\right.$ $\left.{ }^{\circ} \mathrm{C}\right): \delta=5.6 \mathrm{ppm} ;{ }^{13} \mathrm{C}\left\{{ }^{1} \mathrm{H}\right\}$ NMR $\left(125 \mathrm{MHz}, \mathrm{CDCl}_{3}, 22{ }^{\circ} \mathrm{C}\right): \delta=118.0\left(C_{5} \mathrm{Me}_{5}\right), 12.3 \mathrm{ppm}$ $\left(\mathrm{C}_{5} \mathrm{Me}_{5}\right)$.

6: MS $\left(\mathrm{ESI}^{+}\right): \mathrm{m} / \mathrm{z}$ calculated for $\mathrm{C}_{40} \mathrm{H}_{60} \mathrm{OS}_{7} \mathrm{Ta}_{4}+\mathrm{H}^{+}: \mathrm{m} / \mathrm{z}$ 1505.0688, found: $1505.0736 .{ }^{1} \mathrm{H}$ $\operatorname{NMR}\left(500 \mathrm{MHz}, \mathrm{CDCl}_{3}, 22^{\circ} \mathrm{C}\right): \delta=2.16$ (s, 45H; 3×Cp*), $2.01 \mathrm{ppm}\left(\mathrm{s}, 15 \mathrm{H} ; \mathrm{Cp}^{*}\right)$.

Synthesis of 4: In a flame-dried Schlenk tube $\left[\mathrm{Cp}^{*} \mathrm{TaCl}_{4}\right](0.100 \mathrm{~g}, 0.40 \mathrm{mmol})$ was suspended in $20 \mathrm{~mL}$ toluene and chilled to $-78{ }^{\circ} \mathrm{C}$. Then the resultant solution was added to a freshly prepared solution of $\mathrm{Li}\left[\mathrm{BH}_{2} \mathrm{Se}_{3}\right]$ in toluene. The reaction mixture was slowly warmed to room temperature over $1 \mathrm{~h}$ under stirring condition and then heated to $80^{\circ} \mathrm{C}$ for $48 \mathrm{hrs}$. The volatile components were removed under vacuum and the remaining residue was extracted into $n$-hexane and passed through Celite. After removal of the solvent, the residue was subjected to chromatographic work-up by using TLC plates. Elution with $n$-hexane/ $\mathrm{CH}_{2} \mathrm{Cl}_{2}(70: 30 \mathrm{v} / \mathrm{v})$ afforded orange compound 4 (solid, $0.076 \mathrm{~g}, 12 \%$ ).

4: HRMS $\left(\mathrm{ESI}^{+}\right): \mathrm{m} / \mathrm{z}$ calculated for $\mathrm{C}_{30} \mathrm{H}_{46} \mathrm{BSe}_{6} \mathrm{Ta}_{3}+\mathrm{H}^{+}$: 1440.7202, found: $1440.7198 .{ }^{1} \mathrm{H}$ NMR (500 MHz, $\left.\mathrm{CDCl}_{3}, 22{ }^{\circ} \mathrm{C}\right): \delta=2.33(\mathrm{~s}, 45 \mathrm{H} ; 3 \times \mathrm{Cp} *), 4.71 \mathrm{ppm}\left(\mathrm{B}-\mathrm{H}_{\mathrm{t}}\right) ;{ }^{11} \mathrm{~B}\left\{{ }^{1} \mathrm{H}\right\}$ NMR 
(160 MHz, $\left.\mathrm{CDCl}_{3}, 22{ }^{\circ} \mathrm{C}\right): \delta=-11.2 \mathrm{ppm} ;{ }^{13} \mathrm{C}\left\{{ }^{1} \mathrm{H}\right\}$ NMR (125 MHz, $\left.\mathrm{CDCl}_{3}, 22{ }^{\circ} \mathrm{C}\right): \delta=115.4$ $\left(C_{5} \mathrm{Me}_{5}\right), 13.3 \mathrm{ppm}\left(\mathrm{C}_{5} \mathrm{Me}_{5}\right)$; IR (hexane, $\left.\mathrm{cm}^{-1}\right): 2458.8\left(\mathrm{~B}-\mathrm{H}_{\mathrm{t}}\right)$.

Synthesis of 5: In a flame-dried Schlenk tube a suspension of [Cp*TaCl 4$](0.200 \mathrm{~g}, 0.80 \mathrm{mmol})$ in $20 \mathrm{~mL}$ toluene at $-78{ }^{\circ} \mathrm{C}$ was charged with a freshly prepared solution of $\mathrm{Li}\left[\mathrm{BH}_{2} \mathrm{Te}_{3}\right]$. The reaction mixture was slowly warmed to room temperature over $1 \mathrm{~h}$ under stirring condition and then heated to $80^{\circ} \mathrm{C}$ for $48 \mathrm{hrs}$. The volatile components were removed under vacuum and the residue was extracted into $n$-hexane and passed through Celite. After removal of the solvent, the residue was subjected to chromatographic work-up by using TLC plates. Elution with $n$ hexane/ $\mathrm{CH}_{2} \mathrm{Cl}_{2}(80: 20 \mathrm{v} / \mathrm{v}$ ) yellow 5 (solid, $0.024 \mathrm{~g}, 6 \%)$.

5: ${ }^{1} \mathrm{H}$ NMR (500 MHz, $\left.\mathrm{CDCl}_{3}, 22{ }^{\circ} \mathrm{C}\right): \delta=2.17 \mathrm{ppm}(\mathrm{s}, 30 \mathrm{H} ; 2 \times \mathrm{Cp} *) ;{ }^{13} \mathrm{C}\left\{{ }^{1} \mathrm{H}\right\}$ NMR $(125 \mathrm{MHz}$, $\left.\mathrm{CDCl}_{3}, 22{ }^{\circ} \mathrm{C}\right): \delta=110.0\left(\mathrm{C}_{5} \mathrm{Me}_{5}\right), 11.7 \mathrm{ppm}\left(\mathrm{C}_{5} \mathrm{Me}_{5}\right)$.

X-ray Structure Determination. The crystal data for 2, 3, 4 and 5 were collected and integrated using a Bruker axs kappa APEX-II CCD diffractometer with graphite-monochromated $\mathrm{MoK}_{\alpha}(\lambda$ $=0.71073 \AA$ ) radiation at $296 \mathrm{~K}$. The crystal data for $\mathbf{6}$ was collected and integrated using a Bruker APEXII AXS diffractometer, equipped with a CCD detector, using $\mathrm{MoK}_{\alpha}$ radiation $(\lambda=$ $0.71073 \AA$ ) at $150(2) \mathrm{K}$. The structures were solved by heavy atom methods using SHELXS-97 or SIR92 and refined using SHELXL-2014. ${ }^{44}$ 
Table 3. Crystallographic Data and Structure Refinement Information for 2-6.

\begin{tabular}{|c|c|c|c|c|c|}
\hline & 2 & 3 & 4 & 5 & 6 \\
\hline CCDC No. & 1845949 & 1845950 & 1845951 & 1845952 & 1845953 \\
\hline $\begin{array}{l}\text { Empirical } \\
\text { formula }\end{array}$ & \multicolumn{3}{|c|}{$\mathrm{C}_{31} \mathrm{H}_{48} \mathrm{BCl}_{2} \mathrm{~S}_{7} \mathrm{Ta}_{3} \mathrm{C}_{30} \mathrm{H}_{45} \mathrm{BClS}_{6} \mathrm{Ta}_{3} \mathrm{C}_{32} \mathrm{H}_{50} \mathrm{BCl}_{4} \mathrm{Se}_{6} \mathrm{Ta}_{3}$} & \multicolumn{2}{|c|}{$\mathrm{C}_{20} \mathrm{H}_{30} \mathrm{Ta}_{2} \mathrm{Te}_{2} \mathrm{C}_{40} \mathrm{H}_{60} \mathrm{OS}_{7} \mathrm{Ta}_{4}$} \\
\hline $\begin{array}{l}\text { Formula } \\
\text { weight }\end{array}$ & 1269.67 & 1187.13 & 1603.94 & 887.54 & 1505.10 \\
\hline Crystal system & monoclinic & triclinic & orthorhombic & triclinic & cubic \\
\hline Space group & $P 2_{1} / n$ & $P-1$ & Pnma & $P-1$ & $\mathrm{P} a-3$ \\
\hline$a(\AA)$ & $12.7180(5)$ & $11.8274(2)$ & $16.7423(11)$ & $9.7538(2)$ & $20.847(2)$ \\
\hline$b(\AA)$ & $14.2356(4)$ & $11.8523(3)$ & $16.5272(13)$ & $10.3073(3)$ & 20.847 \\
\hline$c(\AA)$ & 23.2024(11) & $15.7067(3)$ & $15.4896(12)$ & $14.1709(4)$ & 20.847 \\
\hline$\alpha\left(^{\circ}\right)$ & 90 & 74.1092(11) & 90 & $86.6750(10)$ & 90 \\
\hline$\beta\left(^{\circ}\right)$ & 105.6697(15) & 82.6421(7) & 90 & $88.0540(10)$ & 90 \\
\hline$\gamma\left({ }^{\circ}\right)$ & 90 & $60.1030(8)$ & 90 & $66.7390(10)$ & 90 \\
\hline$V\left(\AA^{3}\right)$ & 4044.6(3) & $1835.75(7)$ & $4286.0(6)$ & 1306.57(6) & $9060(3)$ \\
\hline$Z$ & 4 & 2 & 4 & 2 & 8 \\
\hline$\rho_{\text {calc }}\left(\mathrm{g} / \mathrm{cm}^{3}\right)$ & 2.085 & 2.148 & 2.486 & 2.256 & 2.207 \\
\hline$\mu\left(\mathrm{mm}^{-1}\right)$ & 8.611 & 9.353 & 13.008 & 10.557 & 9.983 \\
\hline$F(000)$ & 2416 & 1124 & 2952 & 800 & 5696 \\
\hline $2 \theta$ range $\left(^{\circ}\right)$ & 3.334 to 49.998 & 2.696 to 50 & 3.582 to 40.226 & $\begin{array}{l}2.878 \\
54.318\end{array}$ & $\mathrm{o}_{5.862}$ to 54.89 \\
\hline $\begin{array}{l}\text { Reflections } \\
\text { collected }\end{array}$ & 29216 & 27446 & 12484 & 22389 & 90464 \\
\hline $\begin{array}{l}\text { Independent } \\
\text { reflections }\end{array}$ & 7116 & 6447 & 2115 & 5790 & 3461 \\
\hline $\begin{array}{l}\text { Final } R \text { indexes } \\
{[\mathrm{I}>=2 \sigma(\mathrm{I})]}\end{array}$ & $\begin{array}{l}R_{1}=0.0487, \\
\mathrm{w} R_{2}=0.1141\end{array}$ & $\begin{array}{l}R 1=0.0328 \\
\mathrm{w} R 2=0.0714\end{array}$ & $\begin{array}{l}R_{1}=0.0604, \\
\mathrm{w} R_{2}=0.1173\end{array}$ & $\begin{array}{l}R_{1}=0.0400, \\
\mathrm{w} R_{2}=0.0919\end{array}$ & $\begin{array}{c}R_{1}=0.0466, \\
9 \mathrm{w} R_{2}=0.0932\end{array}$ \\
\hline $\begin{array}{l}\mathrm{R} \text { indexes [all } \\
\text { data] }\end{array}$ & $\begin{array}{l}R_{1}=0.0822, \\
\mathrm{w} R_{2}=0.1351\end{array}$ & $\begin{array}{l}R 1=0.0421 \\
\mathrm{w} R 2=0.0759\end{array}$ & $\begin{array}{l}R_{1}=0.1038 \\
\mathrm{w} R_{2}=0.1375\end{array}$ & $\begin{array}{l}R_{1}=0.1044, \\
\mathrm{w} R_{2}=0.1192\end{array}$ & $\begin{array}{c}R_{1}=0.0585 \\
2 \mathrm{w} R_{2}=0.1046\end{array}$ \\
\hline
\end{tabular}


Computational Details. The quantum chemical calculations were carried out for 1-6 using DFT as implemented in the Gaussian09 package. $^{29}$ The calculations were performed with the Cp analogues, instead of $\mathrm{Cp}^{*}$ in order to save computing time. Without any symmetry restrictions, all the geometry optimizations were carried out in gaseous state, (no solvent effect) using PBE0 functional $^{45}$ in combination with triple- $\zeta$ quality basis set Def2-SVP. The natural bond orbital (NBO) analysis $^{46}$ within the Gaussian09 package was carried out at PBE0/Def2-SVP level of theory. The ChemCraft package ${ }^{47}$ was used for the visualizations.

\section{ASSOCIATED CONTENT}

Supporting Information. The supplementary spectroscopic data. DFT-computed results for 1-6 and other computational details. This material is available free of charge via the internet at http://pubs.acs.org.

\section{AUTHOR INFORMATION}

\section{Corresponding Author}

*E-mail: sghosh@iitm.ac.in. Tel: +91-44-22574230. Fax: +91 44-22574202

\section{Notes}

The authors declare no competing financial interest.

\section{ACKNOWLEDGMENT}

Generous support of the Science and Engineering Research Board, SERB (Project No. EMR/2015/001274), New Delhi, India, is gratefully acknowledged. S. K. thank IIT Madras for fellowship. K. S. and B. K. thank CSIR and SERB National Post-Doc fellowship (Project No. 
PDF/2016/003998), respectively, for fellowships. Computational facilities of IIT Madras are gratefully acknowledged.

\section{REFERENCES}

(1) (a) Fehlner, T. P. Inorganometallic Chemistry; Ed. Plenum: New York, 1992; (b) Fehlner, T. P.; Halet, J.-F.; Saillard, J.-Y. Molecular Clusters. A Bridge to Solid-State Chemistry; Cambridge University Press: New York, 2007. (c) Gilbert, K. B.; Boocock, S. K.; Shore, S. G. in Comprehensive Organometallic Chemistry, Wilkinson, G.; Abel, E. W.; Stone, F. G. A. (Eds.), pp. 879, Pergamon, New York, (1982) Part 6, Chapter 41.

(2) (a) Roy, D. K.; Bose, S. K.; Anju, R. S.; Mondal, B.; Ramkumar, V.; Ghosh, S. Boron Beyond the Icosahedral Barrier: A 16-Vertex Metallaborane. Angew. Chem., Int. Ed. 2013, 52, 3222-3226; (b) Roy, D. K.; Mondal, B.; Shankhari, P; Anju, R. S.; Geetharani, K.; Mobin, S. M.; Ghosh, S. Supraicosahedral Polyhedra in Metallaboranes: Synthesis and Structural Characterization of 12-, 15-, and 16-Vertex Rhodaboranes. Inorg. Chem. 2013, 52, 6705-6712; (c) Roy, D. K.; Ghosh, S.; Halet, J.-F. Beyond the Icosahedron: The Quest for High- Nuclearity Supraicosahedral Metallaboranes. J. Cluster Sci. 2014, 25, 225-237.

(3) (a) Perla, L. G.; Sevov, S. C. $\left[\mathrm{Bi}_{12} \mathrm{Ni}_{7}(\mathrm{CO})_{4}\right]^{4-}$ : Aggregation of Intermetalloid Clusters by Their Thermal Deligation and Oxidation. Inorg. Chem. 2015, 54, 8401-8405. (b) Perla, L. G.; Sevov, S. C. Cluster Fusion: Face-Fused Nine-Atom Deltahedral Clusters in $\left[\mathrm{Sn}_{14} \mathrm{Ni}(\mathrm{CO})\right]^{4-}$ Angew. Chem. Int. Ed. 2016, 55, 6721-6724. (c) Goicoechea, J. M.; Sevov, S. C. Deltahedral Germanium Clusters: Insertion of Transition-Metal Atoms and Addition of Organometallic Fragments. J. Am. Chem. Soc. 2006, 128, 4155-4161; (d) Tatsumi, K.; Inoue, Y.; Kawaguchi, H.; Kohsaka, M.; Nakamura, A.; Cramer, R. E.; VanDoorne, W.; Taogoshi,§ G. J.; Richmann, P. N. Structural Diversity of Sulfide Complexes 
ContainingHalf-Sandwich $\mathrm{Cp} * \mathrm{Ta}$ and $\mathrm{Cp} * \mathrm{Nb}$ Fragments. Organometallics 1993, 12, 352364.

(4) (a) Whittingham, M. S. Chemistry of intercalation compounds: Metal guests in chalcogenide hosts. Prog. Solid State Chem. 1978, 12, 41-99. (b) Franzen, H. F. Structure and bonding in metal-rich compounds: Pnictides, chalcides and halides. Prog. Solid State Chem. 1978, 12, 1-39. (c) Rao, C. N. R.; Pisharody, K. P. R. Transition metal sulfides. Prog. Solid State Chem. 1976, 10, 207-270. (d) Pan, W.-H.; Johnston, D. C.; McKenna, S. T.; Chianelli, R. R.; Halbert, T. R.; Hutchings, L. L.; Stiefel, E. I. Syntheses and characterization of the cobalt bis-(tetrathiomolybdate) trianion, $\mathrm{Co}\left(\mathrm{MoS}_{4}\right)_{2}{ }^{3-}$. Inorg. Chim. Acta 1985, 97, L17-L19. (e) DuBois, M. R.; VanDerveer, M. C.; DuBois, D. L.; Haltiwanger, R. C.; Miller, W. K. Characterization of reactions of hydrogen with coordinated sulfido ligands. J. Am. Chem. Soc. 1980, 102, 7456-7461.

(5) Conrddson, S. D.; Burgess, B K.; Newton, W. E.; Mortenson, L. E.; Hodgson, K. O. Structural studies of the molybdenum site in the MoFe protein and its FeMo cofactor by EXAFS. J. Am. Chem. Soc. 1987, 109, 7507-7515.

(6) Adams, R. D.; Wang, S. Two-Site Reactivity in a Ligand-Bridged Cluster. The Reaction of $\mathrm{Os}_{4}(\mathrm{CO})_{12}\left(\mu_{3}\right.$-S) with Terminal Acetylenes. Organometallics 1985, 4, 1902-1903.

(7) Rajan, O. A.; McKenna, M.; Noordik, J.; Haltiwanger, R. C.; Rakowski DuBois, M. A Study of Sulfur Ligand Reactivity in Dimeric Dithiolate Complexes of Vanadium and Tungsten Organometallics 1984, 3, 831-840.

(8) Bolinger, C. M.; Rauchfuss, T. B.; Rheingold, A. L. Synthesis and Structures of (i$\left.\operatorname{PrC}_{5} \mathrm{H}_{4}\right)_{2} \mathrm{~V}_{2} \mathrm{~S}_{4}$ and $\left(\mathrm{C}_{5} \mathrm{H}_{5}\right)_{2} \mathrm{~V}_{2} \mathrm{~S}_{2}\left(\mathrm{~S}_{2} \mathrm{C}_{2}\left(\mathrm{CF}_{3}\right)_{2}\right)$ : The Influence of $\pi$-Bonding on the Geometry of the $\mu$-S 2 Ligand. J. Am. Chem. Soc. 1983, 105, 6321-6323. 
(9) Bolinger, C. M.; Rauchfuss, T. B.; Wilson, S. R. 4-Phenyl-1, 2, 4-triazoline-3, 5-dione: A Prosthesis for the $\mu-\eta^{1}-S_{2}$ Ligand in Organovanadium Sulfide Chemistry. J. Am. Chem. Soc. 1984, 106, 7800-7807.

(10) Halbert, T. R.; Pan, W.-H.; Stiefel, E. I. Novel Alkyne Reactions with Binuclear Molybdenum-Sulfur Complexes: Structure of the Dimethyl Acetylenedicarboxylate Adduct of $\left[\mathrm{Mo}_{2} \mathrm{O}_{2}(\mu-\mathrm{S})_{2}\left(\mathrm{~S}_{2}\right)_{2}\right]^{2-} . J$. Am. Chem. Soc. 1983, 105, 5476-5477.

(11) Rauchfuss, T. B.; Rodgers, D. P. S.; Wilson, S. R. Synthesis of a new type of metal dithiolene complex via an induced reaction of acetylenes with a ruthenium sulphide. J. Am. Chem. Soc. 1986, 108, 3114-3115.

(12) Bolinger, C. M.; Rauchfuss, T. B.; Wilson, S. R. Synthesis of organovanadium sulfide cluster compounds via bis(methylcyclopentadienyl)divanadium tetrasulfide. J. Am. Chem. Soc. 1982, 104, 7313-7314.

(13) (a) Mathur, P.; Singh, A. K.; Mohanty, J. R.; Chatterjee, S.; Mobin, S. M. Formation of NMethylated Cyclic Ligand Systems from Unusual Reactions between Trimethylamine NOxide and Acetylenes on $\mathrm{Fe}_{3} \mathrm{Te}_{2}(\mathrm{CO})_{9}$ and Contrast with Reactions on $\mathrm{Fe}_{3} \mathrm{E}_{2}(\mathrm{CO})_{9}(\mathrm{E}=\mathrm{S}$, Se). Organometallics 2008, 27, 5094-5098. (b) Adams, R. D.; Babin, J. E.; Mathur, P.; Natarajan, K.; Wang, J. G. Cluster Synthesis. 25. Synthesis and Characterization of New Mixed-Metal Cluster Complexes by Metal-Metal Exchange. Reactions of the Sulfido Cluster complexes $\mathrm{M}_{3}(\mathrm{CO})_{9}\left(\mu_{3}-\mathrm{CO}\right)\left(\mu_{3}-\mathrm{S}\right)\left(\mathrm{M}=\mathrm{Fe}, \mathrm{Ru}\right.$, and Os) with $\mathrm{W}(\mathrm{CO})_{5} \mathrm{~L}(\mathrm{~L}=\mathrm{CO}$ or $\mathrm{PMe}_{2} \mathrm{Ph}$ ) Inorg. Chem. 1989, 28, 1440-1445. (c) Adams, R. D. The synthesis, structures, bonding and unusual reactivity of sulfido osmium carbonyl cluster compounds. Polyhedron 1985, 4, 2003-2025. (d) Adams, R. D.; Horvath, I. T.; Mathur, P. Cluster Synthesis. 6. The 
Unusual Structures, Bonding, and Reactivity of Some Sulfido-Bridged Tungsten-Osmium Carbonyl Cluster Compounds. J. Am. Chem. Soc. 1984, 106, 6296-6305.

(14) (a) Bolinger, C. M.; Rauchfuss, T. B. Structure of $\left(\mathrm{MeC}_{5} \mathrm{H}_{4}\right)_{2} \mathrm{~V}_{2} \mathrm{~S}_{5}$ and its acetylene addition reaction. Organometallics 1982, 1, 1551-1553; (b) Pasynskii, A. A.; Eremenko, I. L.; Rakitin, Y. V.; Novotortsev, V. M.; Kalinnikov, V.-T. Antiferromagnetic complexes involving metal-metal bonds 1 . Synthesis and molecular structure of an antiferromagnetic dimer with a Cr-Cr bond. J. Organomet. Chem. 1979, 165, 57-64.

(15) (a) Westmeyer, M. D.; Galloway, C. P.; Rauchfuss, T. B. Photoaddition of $\mathrm{Fe}_{2} \mathrm{~S}_{2}(\mathrm{CO})_{6}$ to C60. Inorg. Chem. 1994, 33, 4615-4616; (b) Adams, R. D.; Kwon, O.-S.; Smith, M. D. Insertion of Cyclopentadienylmetal Groups into the S-S Bond of $\mathrm{Mn}_{2}(\mathrm{CO})_{7}\left(\mu-\mathrm{S}_{2}\right)$. Organometallics 2002, 21, 1960-1965.

(16) Bolinger, C. M.; Hoots, J. E.; Rauchfuss, T. B. Intermetallic Chalcogenlde Atom Transfer and the Synthesis of 1, 4-[( $\left(\mathrm{CH}_{3} \mathrm{C}_{5} \mathrm{H}_{4}\right)_{2} \mathrm{Ti}_{2} \mathrm{~S}_{4}$. Organometallics 1982, 1, 223-225.

(17) Appel, A. M.; Lee, S.-J.; Franz, A. J.; DuBois, D. L.; DuBois, M. R. Free Energy Landscapes for S-H Bonds in $\mathrm{Cp}_{2}{ }_{2} \mathrm{Mo}_{2} \mathrm{~S}_{4}$ Complexes. J. Am. Chem. Soc. 2009, 131, 52245232.

(18) Brunner, H.; Gehart, G.; Nuber, B.; Wachter, J.; Ziegier, M. L. The Reaction of $\left[\mathrm{Cp}_{2}{ }_{2} \mathrm{Nb}_{2}\left(\mathrm{~B}_{2} \mathrm{H}_{6}\right)_{2}\right]\left(\mathrm{Cp}^{+}=\eta^{5}-\mathrm{EtMe}_{4} \mathrm{C}_{5}\right)$ with Sulfur: Stabilization of the Tetrathioborato Ligand in Novel Sulfido Niobium Clusters. Angew. Chem., Int. Ed. 1992, 31, 1021-1023.

(19) Fedin, V. P.; Czyzniewska, Prins, R.; Weber, T. Supported molybdenum-sulfur cluster compounds as precursors for HDS catalysts. Appl. Catal. A 2001, 213, 123-132.

(20) (a) Holm, R. H. Trinuclear Cuboidal and Heterometallic Cubane-Type Iron-Sulfur Clusters: New Structural and Reactivity Themes in Chemistry and Biology. Adv. Inorg. 
Chem. 1992, 37, 1-71. (b) Shibahara, T. Cubane and Incomplete Cubane-Type Molybdenum and Tungsten Oxo/Sulfido Clusters. Adv. Inorg. Chem. 1991, 37, 143-173; (c) Lee, S. C.; Lo, W.; Holm, R. H. Developments in the Biomimetic Chemistry of CubaneType and Higher Nuclearity Iron-Sulfur Clusters. Chem. Rev. 2014, 114, 3579-3600.

(21) Anju, R. S.; Saha, K.; Mondal, B.; Dorcet, V.; Roisnel, T.; Halet, J-F; Ghosh, S. Chemistry of Diruthenium Analogue of Pentaborane(9) With Heterocumulenes: Toward Novel Trimetallic Cubane-Type Clusters. Inorg. Chem. 2014, 53, 10527-10535.

(22) Kawaguchi, H.; Tatsumi, K. Synthesis of (Pentamethylcyclopentadienyl)tantalum Sulfido Complexes via $\mathrm{C}-\mathrm{S}$ Bond Cleavage of Triphenylmethanethiolate and Formation of a Novel Trithioborato Ligand. Organometallics 1997, 16, 307-309.

(23) Lalancette, J. M.; Frêche. A.; Monteux. R. Reductions with sulfurated borohydrides. I. Preparation of sulfurated borohydrides. Can. J. Chem. 1968, 46, 2754-2757.

(24) Lalancette, J. M; Arnac, M. Reductions with sulfurated borohydrides. III. Borohydrides incorporating selenium and tellurium. Can. J. Chem. 1969, 47, 3695-3697.

(25) Ramalakshmi, R.; Saha, K.; Paul, A.; Ghosh, S. Reactivity of [Cp*Mo(CO) $\left.{ }_{3} \mathrm{Me}\right]$ with chalcogenated borohydrides $\mathrm{Li}\left[\mathrm{BH}_{2} \mathrm{E}_{3}\right]$ and $\mathrm{Li}\left[\mathrm{BH}_{3} \mathrm{EFc}\right]\left(\mathrm{Cp}^{*}=\left(\eta^{5}-\mathrm{C}_{5} \mathrm{Me}_{5}\right) ; \mathrm{E}=\mathrm{S}\right.$, Se or Te; Fc $\left.=\left(\mathrm{C}_{5} \mathrm{H}_{5}-\mathrm{Fe}-\mathrm{C}_{5} \mathrm{H}_{4}\right)\right)$. J. Chem. Sci. 2016, 128, 1025-1032.

(26) Kennedy, J. D. The Polyhedral Metallaboranes Part II. Metallaboranes Clusters with Eight Vertices and More. Prog. Inorg. Chem. 1986, 34, 211-434.

(27) Bowser, J. R.; Bonny, A.; Pipal, J. R.; Grimes, R. N. Nickel-boron "hybrid" clusters. Synthesis of polyhedral nickelaboranes and nickelacarboranes from small borane and carborane anions. Crystal structure of $\left(\eta^{5}-\mathrm{C}_{5} \mathrm{H}_{5}\right)_{4} \mathrm{Ni}_{4} \mathrm{~B}_{4} \mathrm{H}_{4}$. J. Am. Chem. Soc. 1979, 101, 6229-6236. 
(28) Lei, X.; Shang, M.; Fehlner, T. P. Synthesis and Characterization of $(\mathrm{Cp} * \mathrm{Ru})_{3} \mathrm{Co}(\mathrm{CO})_{2}\left(\mu_{3^{-}}\right.$ CO $) \mathrm{B}_{3} \mathrm{H}_{3} \quad\left(\mathrm{Cp}^{*}=\eta^{5}-\mathrm{C}_{5} \mathrm{Me}_{5}\right):$ A Metallaborane with Cubane Cluster Structure. Organometallics 2000, 19, 4429-4431.

(29) Frisch, M. J.; Trucks, G. W.; Schlegel, H. B.; Scuseria, G. E.; Robb, M. A.; Cheeseman, J. R.; Scalmani, G.; Barone, V.; Mennucci, B.; Petersson, G. A.; Nakatsuji, H.; Caricato, M.; Li, X.; Hratchian, H. P.; Izmaylov, A. F.; Bloino, J.; Zheng, G.; Sonnenberg, J. L.; Hada, M.; Ehara, M.; Toyota, K.; Fukuda, R.; Hasegawa, J.; Ishida, M.; Nakajima, T.; Honda, Y.; Kitao, O.; Nakai, H.; Vreven, T.; Montgomery, J. A., Jr.; Peralta, J. E.; Ogliaro, F.; Bearpark, M.; Heyd, J. J.; Brothers, E.; Kudin, K. N.; Staroverov, V. N.; Keith, T.; Kobayashi, R.; Normand, J.; Raghavachari, K.; Rendell, A.; Burant, J. C.; Iyengar, S. S.; Tomasi, J.; Cossi, M.; Rega, N.; Millam, J. M; Klene, M.; Knox, J. E.; Cross, J. B.; Bakken, V.; Adamo, C.; Jaramillo, J.; Gomperts, R.; Stratmann, R. E.; Yazyev, O.; Austin, A. J.; Cammi, R.; Pomelli, C.; Ochterski, J. W.; Martin, R. L.; Morokuma, K.; Zakrzewski, V. G.; Voth, G. A.; Salvador, P.; Dannenberg, J. J.; Dapprich, S.; Daniels, A. D.; Farkas, O.; Foresman, J. B.; Ortiz, J. V.; Cioslowski, J.; Fox, D. J. Gaussian 09, Revision C.01; Gaussian, Inc.: Wallingford, CT, 2010.

(30) Winkler, U.; Khan, M. A.; Nicholas, K. M. Atom addition and insertion reactions of (MeCp) $)_{2} \mathrm{Ta}(\mathrm{H}) \mathrm{CO}$ with sulfur, tellurium, carbonyl sulfide and carbon disulfide. Inorg. Chem. Comm. 1998, 1, 317-319.

(31) Herberhold, M.; Peukert, J.; Kruger, M.; Daschner, D.; Milius, W. Binuclear CpV, Cp*V, and $\mathrm{Cp}^{*} \mathrm{Ta}$ complexes containing organochalcogenolato bridges, $\mu$-ER (E = sulfur, selenium, tellurium; R = methyl, phenyl, and ferrocenyl). Z. Anorg. Allg. Chem. 2000, 626, 1289-1295. 
(32) $\mathrm{LiBH}_{4}$.THF was used for the in-situ generation of $\mathrm{Li}\left[\mathrm{BH}_{2} \mathrm{~S}_{3}\right]$ and it is assumed that the oxo group in compound $\mathbf{6}$ probably has come from the cleavage of THF (present in the reaction mixture in trace amount). (a) Aspinall, H. C.; Tillotson, M. R. Rare Earth Azatrane Chemistry: Facile Cleavage of THF To Give a $\mathrm{Y}_{2} \mathrm{Li}_{3} \mathrm{O}$ Cluster. Inorg. Chem., 1996, 35, 2163-2164; (b) Bose, S. K.; Geetharani, K.; Varghese, B.; Ghosh, S. Unusual Organic Chemistry of a Metallaborane Substrate: Formation of Tantalaborane Complex with Bridging Acyl Group $\left(\mu, \eta^{2}\right)$. Inorg. Chem., 2010, 49, 6375-6377.

(33) Haiduc, I. Inverse coordination - An emerging new chemical concept. Oxygen and other chalcogens as coordination centers. Coord. Chem. Rev. 2017, 338, 1-26.

(34) Melník, M.; Koman, M.; Ondrejovič, G. Tetramers $\mathrm{Cu}_{4}\left(\mu_{4}-\mathrm{O}\right)(\eta-\mathrm{X})_{6}\left(\mathrm{~L}_{4}\right)$ : Analysis of structural data. Coord. Chem. Rev. 2011, 255, 1581-1586.

(35) (a) Bertrand, J. A.; Kelley, J. A. Five-Coordinate Complexes. II.1 Trigonal Bipyramidal Copper(II) in a Metal Atom Cluster. J. Am. Chem. Soc., 1966, 88, 4746-4747. (b) Kilbourn, B. T.; Dunitz, J. D. The crystal and molecular structure of $\mu_{4}$-oxohexa- $\mu-$ chlorotetrakis (pyridine copper (II)), $\mathrm{Cu}_{4} \mathrm{Cl}_{6} \mathrm{O}_{4} 4 \mathrm{C}_{5} \mathrm{H}_{5} \mathrm{~N}$, a polynuclear copper complex. Inorg. Chim. Acta. 1967, 1, 209-216. (c) Belford, R.; Fenton, D. E.; Truter, M. R. Reactions of NNN'N'-tetra-alkylethylenediamines with copper(II)halides and the crystal structure of $\quad$ bis(NNN'N'-tetraethylethylenediammonium) hexa- $\mu$-chloro- $\mu_{4}$-oxo tetra[chlorocuprate(II)]. J. Chem. Soc., Dalton Trans. 1972, 2345-2350.

(36) (a) Makáňová, D.; Ondrejovič, G. Stabilization of copper(II) relative to copper(I) in tetranuclear $\mathrm{Cu}_{4} \mathrm{OX}_{6} \mathrm{~L}_{4}$ complexes Polyhedron 1989, 8, 2469-2471. (b) Becker, S.; Behrens, U.; Schindler, S. Investigations Concerning $\left[\mathrm{Cu}_{4} \mathrm{OX}_{6} \mathrm{~L}_{4}\right]$ Cluster Formation of 
Copper(II) Chloride with Amine Ligands Related to Benzylamine. Eur. J. Inorg. Chem. 2015, 2437-2447.

(37) (a) Chiarella, G. M.; Melgarejo, D. Y.; Prosvirin, A. V.; Dunbar, K. R.; Fackler, Jr J. P. Tetranuclear, Oxygen Centered Copper(II) Clusters Linked Together with GuanidineGuanidinate Ligands. J. Clust. Sci. 2010, 21, 551-565. (b) Mishra, A. K.; Verma, S. Decanuclear Copper Framework Supported by a Tripodal Adenine Ligand. Inorg. Chem. 2010, 49, 3691-3693. (c) Lobana, T. S.; Sultanaa, R.; Butcher, R. J. A Sandmeyer type reaction for bromination of 2-mercapto-1-methylimidazoline $\left(\mathrm{N}_{2} \mathrm{C}_{4} \mathrm{H}_{6} \mathrm{~S}\right)$ into 2-bromo-1methyl-imidazole $\left(\mathrm{N}_{2} \mathrm{C}_{4} \mathrm{H}_{5} \mathrm{Br}\right)$ in presence of copper(I) bromide. Dalton Trans. 2011, 40, 11382-11384. (d) Becker, S.; Dürr, M.; Miska, A.; Becker, J.; Gawlig, C.; Behrens, U.; Ivanović-Burmazović, I.; Schindler, S. Copper Chloride Catalysis: Do $\mu_{4}$-Oxido Copper Clusters Play a Significant Role? Inorg. Chem. 2016, 55, 3759-3766.

(38) Stucky, G.; Rundle, R. E. The Crystal and Molecular Structure of $\mathrm{Mg}_{4} \mathrm{Br}_{6} \mathrm{O}_{4} \mathrm{C}_{4} \mathrm{H}_{10} \mathrm{O}$, a Grignard Reagent Oxidation Product. J. Am. Chem. Soc. 1964, 86, 4821-4825.

(39) Gaffney, C.; Harrison, P. G.; King, T. J. The crystal and molecular structure of adamanta( $\mu_{4}$-oxo-hexakis( $\mu$-triphenylsiloxy)-tetralead(II). Chem. Commun. 1980, 1251-1252.

(40) Cotton, F. A.; Murillo, C. A.; Pascual, I. First Cr(II) Complex with a Tetrahedral $\mathrm{M}_{4}\left(\mu_{4}-\mathrm{O}\right)$ Core: $\left[\mathrm{M}_{4}\left(\mu_{4}-\mathrm{O}\right)(\mu-\mathrm{Cl})_{6}(\mathrm{THF})_{4}\right]$. Inorg. Chem. 1999, 38, 2746-2749.

(41) Beagley, B.; McAuliffe, C. A.; Rory, P. P. M.; Ndifon, P. T.; Pritchard, R. G. The X-ray crystal structure of $\mu_{4}$-Oxo-hexa- $\mu$-iodotetrakis[tripropylphosphinemanganese(II)], a manganese(II) cluster derived from the interaction of di-iodotripropylphosphinemanganese(II) with dioxygen. J. Chem. Soc., Chem. Commun. 1990, 309-310. 
(42) Al-Juaid, S. S.; Buttrus, N. H.; Eaborn, C.; Hitchcock, P. B.; Roberts, A. T. L.; Smith, J. D.; Sullivan, A. C. Novel alkylmetal hydroxides. The crystal and molecular structures of bis( $\mu$-hydroxy)-bis $\{$ tris(dimethylphenylsilyl)methylzinc $\},\left[\left\{\left(\mathrm{Me}_{2} \mathrm{PhSi}\right)_{3} \mathrm{CZnOH}\right\}_{2}\right]$ and $\mu_{4^{-}}$ oxo-hexa( $\mu$-hydroxy)tetrakis \{tris(trimethylsilyl)methylindium $\}, \quad\left[\mathrm{O}\left\{\left(\mathrm{Me}_{3} \mathrm{Si}\right)_{3} \mathrm{CIn}\right\}_{4}(\mathrm{OH})_{6}\right]$. J. Chem. Soc., Chem. Commun. 1986, 908-909.

(43) Tonzetich, Z. J.; Eisenberg, R. Luminescent $\eta^{5}$-pentamethylcyclopentadienyl tantalum(V) complexes: synthesis, characterization, and emission spectroscopy. Inorg. Chim. Acta. 2003, 345, 340-344.

(44) Spectroscopic details of compound 1: ${ }^{1} \mathrm{H}$ NMR (500 MHz, $\mathrm{CDCl}_{3}, 22{ }^{\circ} \mathrm{C}$ ): $\delta=2.22$ (s, 45H; 3×Cp*), $4.74 \mathrm{ppm}\left(\mathrm{B}-\mathrm{H}_{\mathrm{t}}\right) ;{ }^{11} \mathrm{~B}\left\{{ }^{1} \mathrm{H}\right\} \mathrm{NMR}\left(160 \mathrm{MHz}, \mathrm{CDCl}_{3}, 22{ }^{\circ} \mathrm{C}\right): \delta=0.3 \mathrm{ppm}$; ${ }^{13} \mathrm{C}\left\{{ }^{1} \mathrm{H}\right\} \operatorname{NMR}\left(125 \mathrm{MHz}, \mathrm{CDCl}_{3}, 22{ }^{\circ} \mathrm{C}\right): \delta=117.4\left(\mathrm{C}_{5} \mathrm{Me}_{5}\right), 12.9 \mathrm{ppm}\left(\mathrm{C}_{5} \mathrm{Me}_{5}\right)$.

(45) (a) Sheldrick, G. M. SHELXS-97; University of Göttingen: Göttingen, Germany, 1997. (b) SIR92: Altomare, A.; Cascarano, G.; Giacovazzo, C.; Guagliardi, A. Completion and Refinement of Crystal Structures with SIR92. J. Appl. Crystallogr. 1993, 26, 343-350. (c) Sheldrick, G. M. SHELXL: Program for Crystal Structure Refinement, version 2014/3; University of Göttingen: Göttingen, Germany, 2014.

(46) Perdew, J. P.; Burke, K.; Ernzerhof, M. Generalized Gradient Approximation Made Simple. Phys. Rev. Lett. 1996, 77, 3865-3868.

(47) (a) Weinhold, F.; Landis, C. R. Valency and bonding: A natural bond orbital donor acceptor perspective; Cambridge University Press: Cambridge, U.K, 2005. (b) Reed, A. E.; Curtiss, L. A.; Weinhold, F. Intermolecular Interactions from a Natural Bond Orbital, Donor-Acceptor Viewpoint. Chem. Rev. 1988, 88, 899-926.

(48) Zhurko, G. A. http://www.chemcraftprog.com. 


\section{For Table of Contents Only}

Synthesis and structures of cubane-type organotantalum sulfido cluster with a missing vertex (A) and an adamantane-like inorganic sulfide cluster having an $\mu_{4}$-oxo moiety (B) are reported here (see picture).

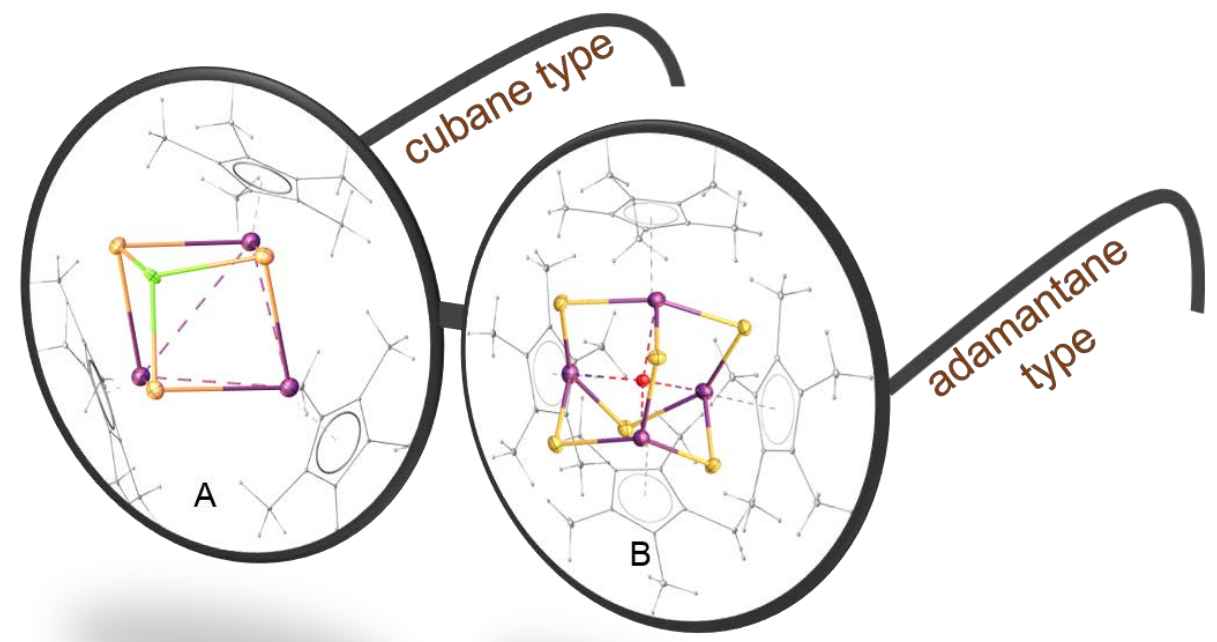

